\title{
Aleksander Gomola, Bóg kobiet. Studium językoznawczo-teologiczne, Wydawnictwo Biblos, Tarnów 2010, ss. 304 (Teolingwistyka, 7)
}

Badacze języka religijnego od dawna zastanawiają się nad tym, jak mówić o Bogu. Odpowiedzi na tak postawione pytanie szukają nie tylko w teologii, ale również w naukach humanistycznych, w tym w językoznawstwie. W ten nurt poszukiwań wpisuje się książka Aleksandra Gomoli pt. Bóg kobiet. Studium językoznawczo-teologiczne.

Książka składa się ze wstępu (s. 7-10), pięciu rozdziałów (s. 11-265), zakończenia (s. 267-269), bibliografii (s. 271-297) i spisu treści (s. 299-303).

Wstęp rozpoczyna się od przedstawienia lingwistycznego kontekstu uzasadniającego temat publikacji. Po nim następuje omówienie celów, które przyświecały autorowi. W dalszej kolejności znajduje się opis struktury pracy uzupełniony uwagami na temat materiału źródłowego i zastosowanych narzędzi badawczych. Końcowy fragment wstępu autor poświęca prezentacji stanu badań, czyli temu - kto, kiedy, pod jakim kątem i w jakim celu badał wykorzystane w pracy źródła.

W pierwszym rozdziale jest mowa o najważniejszych założeniach semantyki kognitywnej, takich jak: zasada ucieleśnienia, kognitywna teoria metafory oraz pojęcie modelu poznawczego i stereotypu. Wyjątkowe jednak miejsce zajmuje w nim teoria amalgamatów Fauconniera i Turnera, potraktowana w pracy jako główne narzędzie badawcze.

Rozdział drugi przedstawia założenia i cele teologii feministycznej jako teologii języka poddającej krytycznej analizie tradycyjne wyobraże- nia Boga w doktrynie chrześcijańskiej. Ponadto w rozdziale tym są omówione podobieństwa i różnice między tą teologią a językoznawstwem kognitywnym, dotyczące zasady ucieleśnienia jako punktu wyjścia w konceptualizacji rzeczywistości, w tym domeny „Bóg”.

Po przedstawieniu najważniejszych tezjęzykoznawstwa kognitywnego i zwięzłej charakterystykiteologii feministycznej, w kolejnym rozdziale autor skupia się na języku religijnym jako miejscu spotkania obu dyscyplin. W pierwszej części przedstawia najważniejsze stanowiska filozoficzne i językoznawcze dotyczące wartości poznawczej języka religijnego. Następnie prezentuje syntezę głównych propozycji dotyczących domeny pojęciowej „Bóg”, wypracowanych przez językoznawstwo kognitywne. Na koniec zaś przedstawia wybrane schematy pojęciowe domeny „Bóg” oraz wybrane amalgamaty domeny „Bóg” pojawiające się w Biblii.

Rozdział czwarty książki jest poświęcony analizie amalgamatu BÓG TO OJCIEC w perspektywie historycznej, ze szczególnym uwzględnieniem pism nowotestamentowych oraz współczesnej doktryny katolickiej, takjakją formułuje Katechizm Kościoła Katolickiego.

Na treść rozdziału piątego składają się analizy wyobrażeń Boga najbardziej rozbudowanych i powtarzających się w teologii feministycznej lat osiemdziesiątychi dziewięćdziesiątychubiegłego stulecia. Są to takie wyobrażenia, jak: BÓG TO 
MATKA, WSZECHŚWIAT TO CIAŁO BOGA, BÓG TO PRZYJACIEL.

W zakończeniu autor przypomina główną linię wywodu, prezentuje wnioski z przeprowadzonych analiz i pokazuje nowe obszary badań związanych z teologią feministyczną w ujęciu językoznawstwa kognitywnego.

Tytułksiążkiz punktu widzenia metodologicznego jest poprawny, gdyż jasno określa problem badawczy. Wynika z niego, że przedmiotem zainteresowań Aleksandra Gomoli są wyobrażenia Boga we współczesnej teologii feministycznej (aspekt źródłowy), analizowane z perspektywy językoznawstwa kognitywnego (aspekt doktrynalny).

Z tematem książki ściśle wiąże się jej cel. Zdaniem autora celem tym jest: 1 . „przedstawienie wyczerpującego opisu konceptualizacji domeny «Bóg» w teologii feministycznej, ze szczególnym uwzględnieniem ich nowatorskiego charakteru"; 2. „próba określenia implikacji teologicznych tych konceptualizacji orazichewentualnego wpływu na ksztalt doktryny, gdyby znalazły się one w głównym nurcie przekazu treści wiary" (s. 8). Przyjmując, że zgodnie z definicją słownikową, celem jest wynik każdego racjonalnego działania, coś do czego się dąży, o co się zabiega, to w myśl tego celem recenzowanej publikacjijest - jak słusznie zauważa autor - przedstawienie wyczerpującego opisu konceptualizacji domeny „Bóg” w teologii feministycznej wrazz ich doktrynalnymi implikacjami. Natomiast problemem, czyli „nerwem” przewijającym się przez całość rozważań, niepostawionym wyraźnie przez autora,jest poszukiwanie odpowiedzi na pytanie:Jak językoznawstwo kognitywne radzi sobie z eksploracją wyobrażeń Boga występujących we współczesnej teologii feministycznej?

Materiał źródłowy dla tak zaplanowanych badań stanowią prace tzw. „białego" nurtu teologii feministycznej, określanego także jako euro-amerykańska teologia feministyczna.

Głównym narzędziem badawczym zastosowanym w pracy jest teoria amalgamatu. Wybór tego narzędzia należy uznać za zasadny. Dzięki niemu bowiem autorowi udało się odsłonić sposób myślenia przedstawicielek teologii feministycznej, który doprowadził je do takich a nie innych konceptualizacji domeny „Bóg”.
Zresztą podobnie postępują same przedstawicielki tej teologii, analizując patriarchalne wyobrażenia Boga. One również odwołują się do założeń i propozycji językoznawstwa kognitywnego, przede wszystkim do tego, że języka nie da się oddzielić od naszych sposobów konceptualizacji świata. Dlatego uważają, że oczywiste dla wielu wierzących męskie formy konceptualizacji domeny „Bóg”, takie jak Ojciec, Pan, Król i Władca, nie mają charakteru uniwersalnego, lecz są odzwierciedleniem perspektywy androcentrycznej. Wynika z tego, że autor zastosował w pracy podobne narzędzia do tych, którymi posługuje się teologia feministyczna, krytykując patriarchalne wyobrażenia Boga obecne w teologii, nazwijmy ją na użytek tej recenzji, „tradycyjnej”.

Postępowanie badawcze jest w omawianej publikacji dobrze zaplanowane i ściśle realizowane. Rozpoczyna się ono od zagadnień wprowadzających. Za takie bowiem należy uznać prezentację językoznawstwa kognitywnego, teologii feministycznej i języka religijnego. Poznanie tych założeń stanowi warunek przejścia do następnego zagadnienia, jakim jest analiza amalgamatu BóG TO OJCIEC jako podstawowej konceptualizacji domeny „Bóg” w teologii „tradycyjnej”. Znajomość tego wyobrażenia Boga, treści w nim zawartych i roli, jaką pełni w chrześcijaństwie, daje możliwość pogłębionej analizy podstawowych amalgamatów teologii feministycznej: BÓG TO MATKA, WSZECHŚWIAT TO CIAŁO BOGA, BÓG TO PRZYJACIEL. W tym postępowaniu zastanawia jednak swego rodzaju asymetryczność między teologią „tradycyjną" a teologią feministyczną - w teologii ,tradycyjnej" przeanalizowano jedno wyobrażenie Boga (BÓG TO OJCIEC), a w teologii feministycznej trzy:BÓGTOMATKA, WSZECHŚWIAT TO CIAEO BOGA, BÓG TO PRZYJACIEL. Co by się stało, gdyby na przykład w teologii ,tradycyjnej", dla równowagi, przeanalizowano dwa dodatkowe wyobrażenia: BÓG TO ZBAWICIEL, KOŚCIÓE TO CIAŁO CHRYSTUSA? CZy i w jakim stopniu miałoby to wpływ na wyniki badań?

Wybór właściwego narzędzia badawczego $\mathrm{i}$ konsekwencja w jego stosowaniu doprowadzily autora do osiągnięcia zakładanych we wstępie 
celów. Aleksandrowi Gomoli udało się w sposób przekonujący pokazać językoznawstwo kognitywne, ze swoimi założeniami i posiadanym instrumentarium, jako przydatne w badaniach nad wyobrażeniami Boga, zarówno w teologii „tradycyjnej”, jak i feministycznej.

Za udaną należy też uznać prezentację wyobrażeń Boga stosowanych przez przedstawicielki teologii feministycznej, a mianowicie: BóG TO MATKA, BÓG TO PRZYJACIEL, WSZECHŚWIAT TO CIAŁO BOGA, pomijając mniej znaczące JEZUS TO KLAUN i JEZUS TO TRICKSTER. Domeny wyjściowe, do których one się odwołują oraz treści w nich zawarte, potwierdzają tezę językoznawstwa kognitywnego, że opis świata użytkowników języka, w tym jego abstrakcyjnych aspektów, zawsze dokonuje się z określonej perspektywy i z uwzględnieniem czynników kulturowych danej społeczności językowej.W sytuacji teologii feministycznej jest to perspektywa kobiet świadomych własnej dyskryminacji we wspólnocie wiary, przedstawicielek kultury zachodniej. Nawiasem mówiąc, teza utożsamiania Boga z materialnym wszechświatem (WSZECHŚWIATTO CIAŁO BOGA), choć może bliska mistykom, to jedna z najbardziej ryzykownych tez teologii feministycznej, obok rezygnacji z koncepcji grzechu pierworodnego i wizji „cierpiętliwego” Boga.

Autorowi udało się również odpowiedzieć na pytanie dotyczące implikacji teologicznych wynikających z przyjęcia wyobrażeń Boga proponowanych przez teologię feministyczną. Wyobrażenia te prowadzą do nowych rozwiązań i propozycji w sposobie przedstawiania relacji Bóg - człowiek. Niektóre z nich mieszczą się w ramach ortodoksji chrześcijańskiej i przyczyniają się do nowego mówienia o Bogu, inne zaś przekształcają się w systemy teologiczne różne od chrześcijaństwa, z czego autor zdaje sobie doskonale sprawę.

Książka Aleksandra Gomoli jest dziełem oryginalnym, pierwszym tego rodzaju na gruncie polskim, choć opartym głównie na feministycznej literaturze obcojęzycznej. Jej podstawową zaletą jest to, że autor w sposób obiektywny przedstawia w niej feministyczne wyobrażenia Boga (np. BóG TO MATKA). Takie podejście nie dezawuuje jednak androcentrycznych obrazów Boga obecnych w teologii „tradycyjnej” (np. BóG TO OJCIEC). Autorowi chodzi przede wszystkim o to, by te dwa języki (feministyczny i tradycyjny) wzajemnie się dopełniały, prowadząc do pełniejszego wyobrażenia Boga, zgodnie z sugestią Jana Pawła I, że „Bóg jest naszym ojcem; więcej, jest dla nas matką" (cyt. za: J. Majewski, O gaworzeniu (polemika, „Tygodnik Powszechny”, 2011, nr 12, s. 24).

ks. Wiesław Przyczyna 